Cruisers in the City of Helsinki : Staging the Mobility of Cruise Passengers

\author{
Paananen, Kaisa Karoliina
}

2019-10-20

Paananen , K K \& Minoia , P 2019 , ' Cruisers in the City of Helsinki : Staging the Mobility of

Cruise Passengers ' , Tourism Geographies , vol. 21 , no. 5 , pp. 801-821 . https://doi.org/10.1080/14616688.2018.1

http://hdl.handle.net/10138/309161

https://doi.org/10.1080/14616688.2018.1490341

unspecified

acceptedVersion

Downloaded from Helda, University of Helsinki institutional repository.

This is an electronic reprint of the original article.

This reprint may differ from the original in pagination and typographic detail.

Please cite the original version. 


\section{Cruisers in the City of Helsinki: Staging the Mobility of Cruise Passengers}

Kaisa Paananen

Department of Geoscience and Geography, University of Helsinki, Helsinki, Finland

Paola Minoia

Department of Political and Economic Studies, University of Helsinki, Helsinki, Finland

International cruise passengers moving in urban destinations have particular time limitation that can make enabling and disabling elements of mobility meaningful on the quality of their visit. Identifying these elements is essential to improve their independent movement. Based on a staging mobilities framework that considers the dimensions of physical settings, material spaces, design (PMD), social interactions (SI) and embodied performances (EP) in situ, the research has analysed location-specific information in Helsinki, a popular port of call in the Baltic Sea. The study has used go-along observations and mobile application in data collection. The produced dataset was analysed by combining GIS-methods and content analyses. As a result, five categories were identified under the dimension of PMD: wayfinding tools, unexpected situations, lack of rest spots and walkability. Categories identified under the dimension of SI were local people, service providers and travel companions, and other tourists. Categories identified under the dimension of EP were traffic behaviour, occasioned activities, sense of direction, planning, and time-related anxiety. Urban destinations such as Helsinki can apply these results in practice, to make the movement of independently moving cruise passengers as effortless as possible, contributing to a better experience of the city space for both tourists and other city users. The proposed methodology could also be used to analyse other mobility-related phenomena.

Keywords: tourism mobility, staging mobilities, urban tourism, cruise tourism, Helsinki, port of call 


\section{Introduction}

'Do we have time to visit the church? What if we miss the ship? 'These worries expressed by cruise passengers while moving independently from the port terminal of Helsinki to the city centre, represent their sense of insecurity while moving out of the tourist bubble of the ship (Judd, 1999). Cruise passengers, a category of organized mass tourists (Diedrich 2010), base their feeling of safety from the controlled environment of the ship, where personnel and activities are at their service to fulfil their needs (Jaakson, 2004). When a ship docks on a port of call, passengers have three mobility possibilities: to remain on board inside the safe bubble, to join activities organized by the cruise in the arrival place, or to visit the place independently. The moment of disembarkment at the port is, therefore, quite exciting; often, these daily tourists arrive unprepared to the port of call, and their mental map of the destination is rather uncertain (Aranburu, Plaza \& Esteban, 2016; Lew \& McKercher, 2006; Lynch, 1960).

In Helsinki, out of the $96 \%$ of passengers who depart the cruise, about $60 \%$ take organized tours, and only $35 \%$ move independently (G. P. Wild (International) Limited and Business Research and Economic, 2015). Helsinki's local government, like many other coastal locations, welcomes the city's inclusion in international cruise itineraries because of the positive expectation about economic benefits brought by the disembarking tourists as consumers of goods and users of local transport and other urban services.

The focus of this study is on independent cruise passengers moving inside the destination by walking or using public transportation and aims to shed light on two questions, one substantial and one methodological. The first research question regards the type of urban factors either facilitating or challenging the walking mobility of cruise passengers in the city; the second question looks at the applicability of go-along 
methods for spatial analysis of this tourist mobility. The research is based on an empirical study of Helsinki, a port of call specialized on cruise ships, and where passengers stops to spend only few hours in a daytime (Marti, 1990).

Cruise tourism started in the early 1960s and increased rapidly worldwide, growing from 3.8 million passengers in 1990 to 24.2 million in 2016(Cruise Market Watch, 2016), with estimated 25.3 million passengers for the year 2017 (Cruise Lines International Association (CLIA), 2016).

Earlier studies (e.g. De Cantis, Ferrante, Kahani and Shoval, 2016; Ferrante, De Cantis and Shoval 2016) have demonstrated the relevance of research on cruise passengers' behaviour at the destinations, to ensure good management and provision of the necessary services, and guarantee positive tourist experiences. Tourist usually select the cruises based on ports of call and their attractiveness, and decreases in satisfaction's rates can make their inclusion in cruise tours at risk (Henthorne 2000). Moving from these considerations, our study would like to contribute to the analytical understanding of spatio-temporal data on tourist mobility integrated with qualitative information, to evaluate cruise passengers needs and potentially address problems of access to, and satisfactorily visit of, the city.

\section{Background studies and theoretical framework}

Cruise ship tourism is still of minor interest academically, despite its significant growth and impacts on coastal cities (e.g., De Cantis et al., 2016; Ferrante et al., 2016; Papathanassis \& Beckmann, 2011; Rodrigue \& Notteboom, 2013; Wood, 2000). Previous studies have looked particularly at economic aspects, for instance on produced income at the destinations (e.g. Brida, Bukstein, Garrido \& Tealde, 2012; Satta, Parola, Penco \& Persico, 2015; Penco \& Di Vaio, 2014); passenger satisfaction (Silvestre, Santos \& Ramalho 2008; Satta et al., 2015); preference choices of destinations, returns 
and recommendations (Larsen \& Wolff 2016; Baker \& Fulford 2016; Andriotis \& Agiomirgianakis 2010); or produced environmental and socio-economic impacts, also negative (Brida \& Zapata, 2010; Carić, 2016; Jordan \& Vogt, 2017).

Other researches on ports of call have focused on elements contributing to their quality, for instance in terms of natural and cultural assets, port facilities, security, costs and marketing (Manning 2006); quality of services in the cities, sea, land and air connections (McCalla 1998); proximity to tourist attractions (Çetin Demirel and Yücenur 2011); attractiveness in terms of infrastructures, competitive prices, products and services, with emphasis on market segmentation to satisfy different categories of customers (De Cantis et al. 2016). All these studies have highlighted various structural conditions of mobility of cruise passengers, while behavioural issues in their short visits have been mostly neglected (De Cantis et al., 2016; Ferrante et al., 2016; Brida et al., 2012; Yarnal \& Kerstetter (2005); Xie, Kerstetter \& Mattila 2012). A qualitative study proposed by Andriotis and Agiomirgianakis (2010) about Heraklion, Crete, has shown practical problems encountered by independent tourists even to simply hiring a taxi or finding the main tourist attractions. De Cantis et al. (2016) and Ferrante et al. (2016) have made use of GPS devices to study cruise tourist mobility with the aim to, respectively, identify passenger profiles based on their behaviour at the destination, and to create a database on cruise passengers mobility onshore. Different types of mobile methods for data collection have become popular in tourism studies, using new technology; GPS tracking and recording itineraries (Shoval and Isaacson 2007, McKercher, Shoval, Ng, and Birenboim 2012, Edwards \& Griffin 2013, Shoval \& Ahas 2016), also allowing better understanding of tourist activities and supporting specific travel behaviours (Zheng \& Li, 2017). Moreover, passive mobile positioning has been 
used for collecting big data, e.g. from tourism statistics and geocoded photos (e.g. Ahas, Aasa, Mark, Pae, \& Kull, 2007).

Smartphones and tablets are used to trace locations by GPS, cell-tower identification and Wi-Fi positioning. Even though the development of mobile applications in smartphones has not been used extensively so far, there is still good potential also for enriching data with qualitative information related to the visiting experiences (Shoval \& Ahas 2016, Kang 2016). Furthermore, various technological applications are being developed that are not yet reported in tourism literature.

Our study has used Jensen's staging mobilities framework, an analytical tool that has inspired a new emerging field named mobilities design focusing on physical interventions and design-related decisions that can enable or disable mobile situations (Jensen 2013, 2014a, 2014b, Veijola \& Falin 2016). The staging mobilities framework is located in the new mobilities paradigm (Lanng \& Jensen, 2016; Cresswell 2006; Sheller \& Urry, 2006; Urry 2000, Urry 2010), looking at mobility as an integral part of everyday life. Mobilities are understood in their socio-material configurations (Fullagar, Wilson \& Markwell, 2012; Larsen, 2001; Tranberg Jensen, Gyimothy, \& Jensen, 2015) that are significant in individual social and emotional lives (Urry, 2000)

Jensen's staging mobilities model looks at two levels of staging: from above, regulated by planning, design, regulations, and institutions; and from below, produced by interaction and individual performances. The two levels construct the mobile situation within three dimensions: (1) Physical settings, Material space, and Design (PMD); (2) Social Interaction (SI) and (3) Embodied Performances (EP). In the first dimension, PMD, individuals move and use roads, signs, traffic lights, etc. that are both designed and regulated to facilitate mobility and its speed (Sheller 2017). According to Bissell (2010) mobility also makes use of ordinary materials like laptops, mobile 
phones, and tickets, and therefore, PMD could also include them. These elements do not only occupy the background but are dynamic formations as mobile biotopes: 'Manmade environments where mobility and living are ongoing and constant' (Jensen, 2013: 47-48). Human bodies interact with these environments intended as semiotic systems that can make sense of the mobile situations. Material spaces form the landscapes that are organized from above and at the same time, staged from below, through gestures and bodily postures performed by people. Mobility 'affordance ' (ibid.: pp. 94-95) describes the relationship of the moving body with the material environment that either opens up or narrows down the modes of traveling. Mobility aesthetics (Jensen, 2014a: pp. 48-49) reveals the subjectivity produced by mobile bodies that are affected by particular rationalities, cultural norms, and psychologies. In fact, different kinds of effects like stress and irritation produce an impact on the travel atmosphere (Bissell, 2010) and, consequently on the very act of mobility.

Social interaction (SI) is crucial for understanding mobilities in situ (Jensen, 2013: p. 65). Tourists move within the city with family, friends, partners, groups and with other companies met for example during the cruise or on the street ('temporary congregations'), therefore being 'mobile withs' together. Interactions between mobile bodies may seem random, but constitute a process of negotiation that takes place while in motion ('negotiation in motion': Jensen, 2014a: p. 46): this is rather common in the case of tourists moving in unfamiliar environments. The last dimension, Embedded Performances (EP) explains how the body influences mobility patterns, its movements and 'the mobile self' (Jensen, 2014b).

\section{Study Context}

The case study focuses on the port of call of Helsinki, located on the northern shore of the Baltic Sea. International cruising in this area is seasonal, usually happening during 
the summer months. Figure 1 represents the top cruising destinations in the area, namely: Copenhagen, Stockholm, Rostock, St. Petersburg, Tallinn, Helsinki, and Kiel.

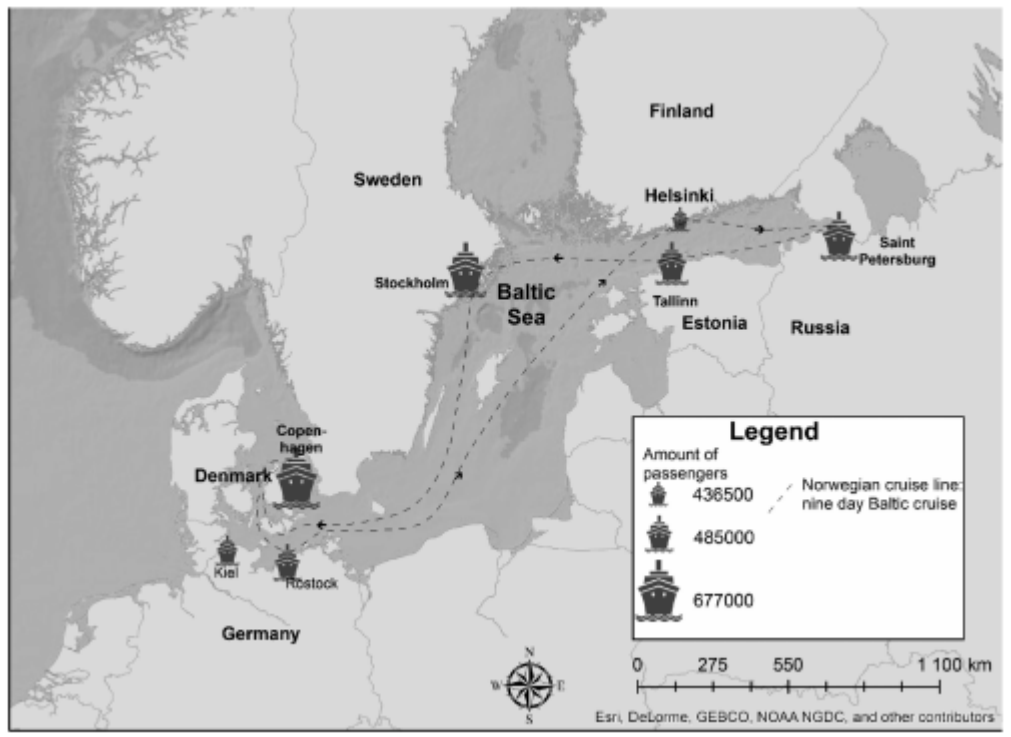

Figure 1: Ports of calls at the Baltic Sea region with most international cruise ship passengers and an example route of one Baltic Sea cruise, the nine days Baltic Cruise of Norwegian Cruise Lines (Authors' own production). Basemap source: Esri, DeLorne, GEBCO, NOAA, NGDC, and other contributors.

The number of passengers has grown in the Baltic region, and more and more visitors disembark in Helsinki. Figure 2: Number of passengers in Helsinki and in the Baltic Sea area in 2000-2016. The scale on the left shows the changes in the whole Baltic Sea area. The scale on the right shows the changes in Helsinki. shows this growing trend. In summer 2016, Helsinki was visited by 409,000 passengers coming from 240 ships (Port of Helsinki, 2017) and originally, mostly from Germany, United States, UK, Spain and Canada (Visit Helsinki, 2016). In 2014, the average time spent in Helsinki was 4.5 hours, while half of the passengers stayed two to three hours onshore; $87 \%$ of the passengers were first-time visitors in the city. The average size of the party 
was two persons, and the average age was 58 years: $48 \%$ were 65 years or older, and only $6 \%$ were under the age of 25 (G.P. Wild 2015).

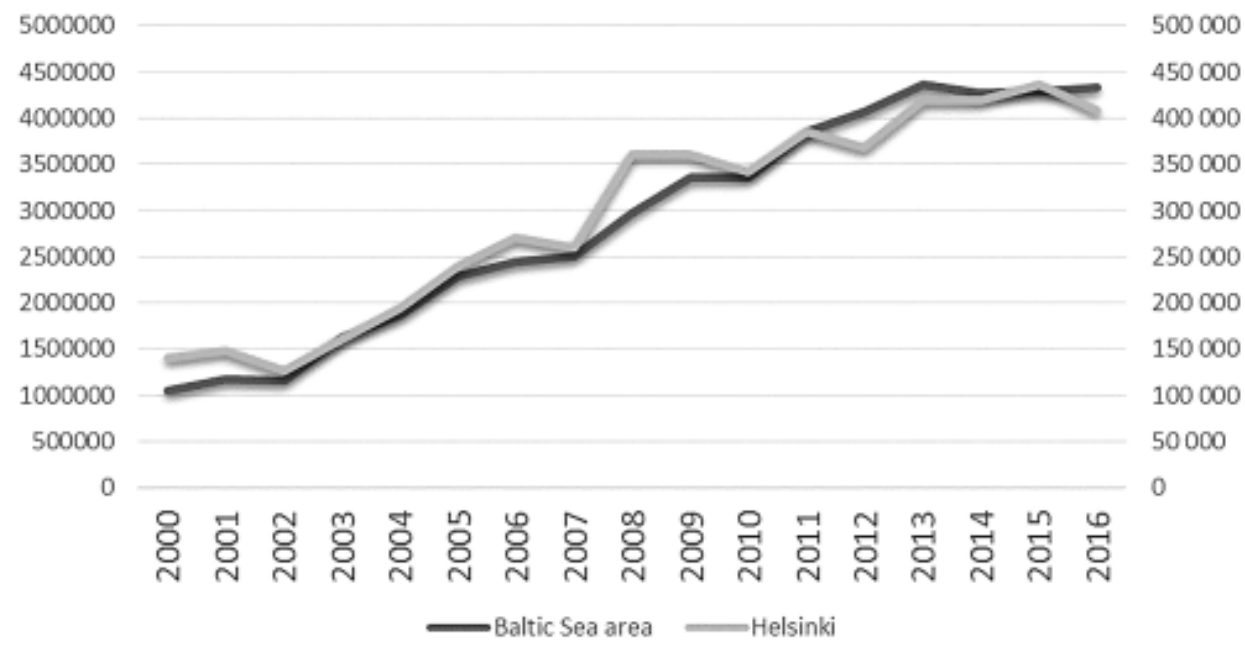

Figure 2: Number of passengers in Helsinki and in the Baltic Sea area in 2000-2016. The scale on the left shows the changes in the whole Baltic Sea area. The scale on the right shows the changes in Helsinki.

Helsinki city has four harbours serving international cruises: Hernesaari, Länsisatama (Western harbour), Eteläsatama (Southern Harbour, including Kanavaterminaali pier) and Katajanokka. As Figure 3 shows, Katajanokka and Eteläsatama are within a short walking distance to Market Square, while Hernesaari and Länsisatama are located, respectively, 4.5 and 4 kilometres away from Market Square. The core historical centre near the seashore and the Cathedral is the most visited area by the short-term tourists in the city. Attractions include historical monuments, museums and other cultural centres, and shopping malls; these latter are especially developed near the Central Railway Station, Mannerheim street and Kamppi area. 


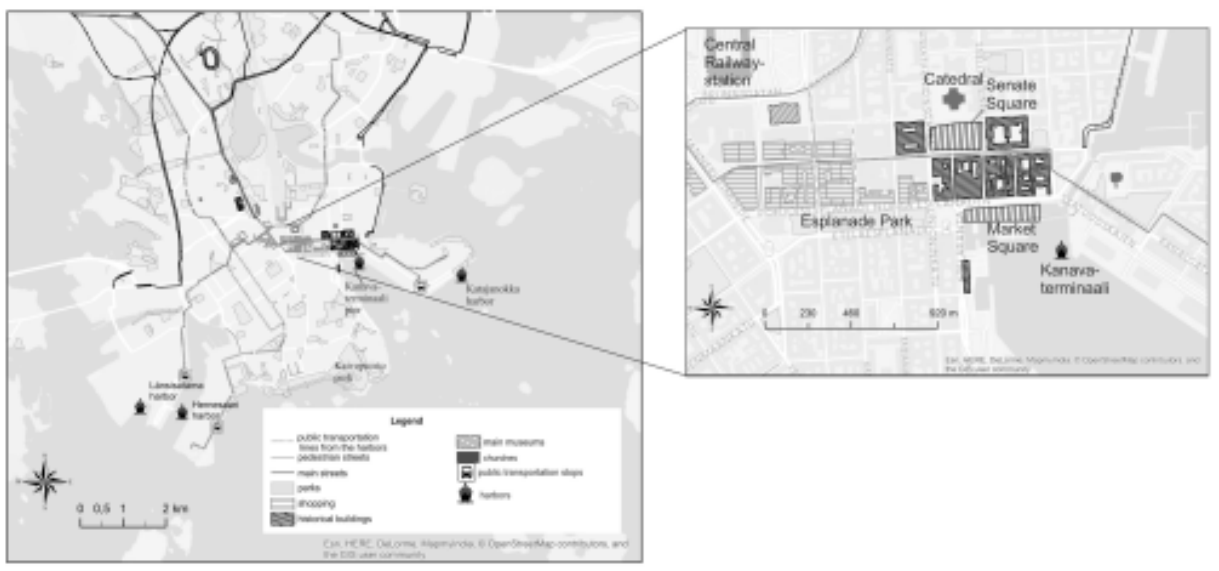

Figure 3: Helsinki city area and the most important tourist attractions. Authors' own production). Basemap source : Esri, HERE, DeLorne, MapmyIndia, C OpenStreetMap contributors, and GIS user community; Contains data from the National Land Survey of Finland Topographic Database 06/2014; (C HSL 2016)

\section{Methodology}

Our study has tested a go-along observation as a data collection method with a mobile application that has allowed recording of qualitative in-depth and place-specific data (Finlay \& Bowman, 2017), with information gathered while visitors were actually moving around (Kusenbach, 2003). This type of qualitative data collection's technique has been used surprisingly rarely in tourism movement studies, although the spatial information produced by tracking and recording tools could also be useful for urban tourism planning. So far, studies influenced by the mobilities' theory have rather used other sorts of qualitative ethnographic field methods, especially embodied and classic ethnographic mapping (Jensen, 2013; Jensen, 2014a). As said, our go-along method made it possible to understand certain phenomena at the same time, place and space of their happening. We used GPS for georeferencing data. Conversations between researcher and the participants in situ could enrich the geographic data giving qualitative value and facilitating their adjustment (as indicated by Kusenbach, 2012). Our observations were conducted with passengers that arrived at all the four harbours of 
Helsinki. Sampling was discretionary: the criteria for informants' selection were chosen beforehand, based on the basic demographic profile of a typical cruise passenger in Helsinki, e.g., nationality, age, and size of the travel group. Informants were approached at their departure from the ship, and the contact time lasted for about one hour during their way into the city. Tourists were asked to report any enabling and disabling element of mobility along their way. Informants paid particular attention to physical features, which were easier to detect and express. Other non-verbal factors regarding social interaction and embedded issues remained mostly unexpressed verbally but still visible and noted by the researcher. The accompanying researcher tried not to affect the route or to give any route suggestions. Observations were recorded with a mobile application that provided space- and time-related information and completed by observation reports written after each tour. The Android operating system mobile application, called Tourist Experience Tracker was designed for this study and now it can be freely downloaded from Google Play Store. We planned the design and content, and the coding was done by a computer science professional, Charlie Hornsby. The application consists of a tracker and a possibility to add comments as well as photos and includes a separate function for adding background information. The application has a feature that gives the possibility to press "thumbs down" when the observed issue affected negatively on the movement and "thumbs up" when it affected positively. The tracking function is based on cell-tower identification and Wi-Fi positioning.

Some methodological challenges regarded the researcher-informants relation during the exercise. Like in qualitative studies in general, the subjectivity of both researchers and researched has to be considered. For us, it was essential to develop a positive connection with the informants from the very beginning, even though the good relationship always activated more interest by the passengers to discuss other issues, 
which interfered with the exercise. Getting people to participate proved to be overall smooth, but approaches were easier when we knew the languages spoken by the tourists. In some cases, we realized that our presence decreased the anxiety of the participants while moving into the city. Practical issues such as weather affected the goalong exercise although only during one tour it was impossible to continue.

Altogether, we conducted 35 observations were involving 61 persons, between May and September 2016. Table 1 presents some characteristics of the study participants.

Table 1. Study participants

\begin{tabular}{|c|c|c|c|c|c|}
\hline Tour month & & Arrival harbor & & Group size & \\
\hline May & 5 & Hernesaari & 11 & one & 2 \\
\hline June & 5 & Kanavaterminaali & 10 & two & 12 \\
\hline July & 11 & Länsisatama & 10 & three & 4 \\
\hline August & 11 & Katajanokka & 4 & four & 11 \\
\hline September & 3 & & & over four & 6 \\
\hline Travel company & & Age & & Nationality & \\
\hline alone & 2 & under 15 & 6 & UK & 12 \\
\hline $\begin{array}{l}\text { family (with } \\
\text { children) }\end{array}$ & 10 & $15-24$ & 7 & USA & 9 \\
\hline $\begin{array}{l}\text { family (without } \\
\text { children) }\end{array}$ & 4 & $35-44$ & 4 & Germany & 6 \\
\hline spouse & 15 & $45-54$ & 12 & Mexico & 2 \\
\hline friends & 2 & $55-64$ & 8 & Spain & 2 \\
\hline co-workers & 2 & over 64 & 12 & France & 1 \\
\hline & & & 12 & \begin{tabular}{|l|} 
The \\
Netherlands
\end{tabular} & 1 \\
\hline & & & & Russia & 1 \\
\hline & & & & Ireland & 1 \\
\hline
\end{tabular}

For the analysis of data, the primary focus was to detect enabling and disabling elements influencing the tourists' mobility towards the city, and within the city centre in the short time span they had. All data included the researchers' notes about the tourists' experiences, including quotes, body language and other expressions of tourists' behaviours while moving; clearly then, the notes reflect the researchers' understanding 
about the situations. Data were georeferenciated, so that all notes had their precise locations.

The data was stored in Google Developers Console and then processed with Atlas.ti-programme for content analysis. The coding was derived from the staging dimensions theory: PMD / enabling or disabling, SI / enabling or disabling, and EP / enabling or disabling. Altogether 271 elements were detected and coded, resulting in 150 disabling elements and 29 enabling elements within the category of PMD; 5 enabling and 23 disabling elements within the category of SI; and 26 disabling and 17 enabling elements under the category of EP.

All the comments under each code were analysed and clustered within specific categories. The space-time information was in json form, and through the program Python, json form was coded into a shapefile able to transform the data into ArcMap. By comparing the routes and time/space information of the comments, the location of the comment could be placed on the map. Then the comments could be classified in ArcMap based on the categories created in the earlier phase.

\section{Results: disabling and enabling categories in cruise passengers' mobility}

The analysis reveals the distribution of the elements PMD, SI and EP along the routes taken by the tourists in the different areas of Helsinki. Most comments were expressed in the core tourist area, where most of the passengers headed during the first hour of their visit. Another area that was pointed by many comments was the Rock Church, reached by bus from Hernesaari harbor. The following sections describe these elements more in detail. Some specific situations are introduced through quotes taken from the go-along notes.

Figure 4 represents Jensen's framework applied to the situation of mobility in Helsinki, after the result given by the content analysis. What needs to be acknowledged 
is that this model is a simplification of the reality, since enabling or disabling categories rarely work on their own but are usually intertwined and occurring in the same space and time.

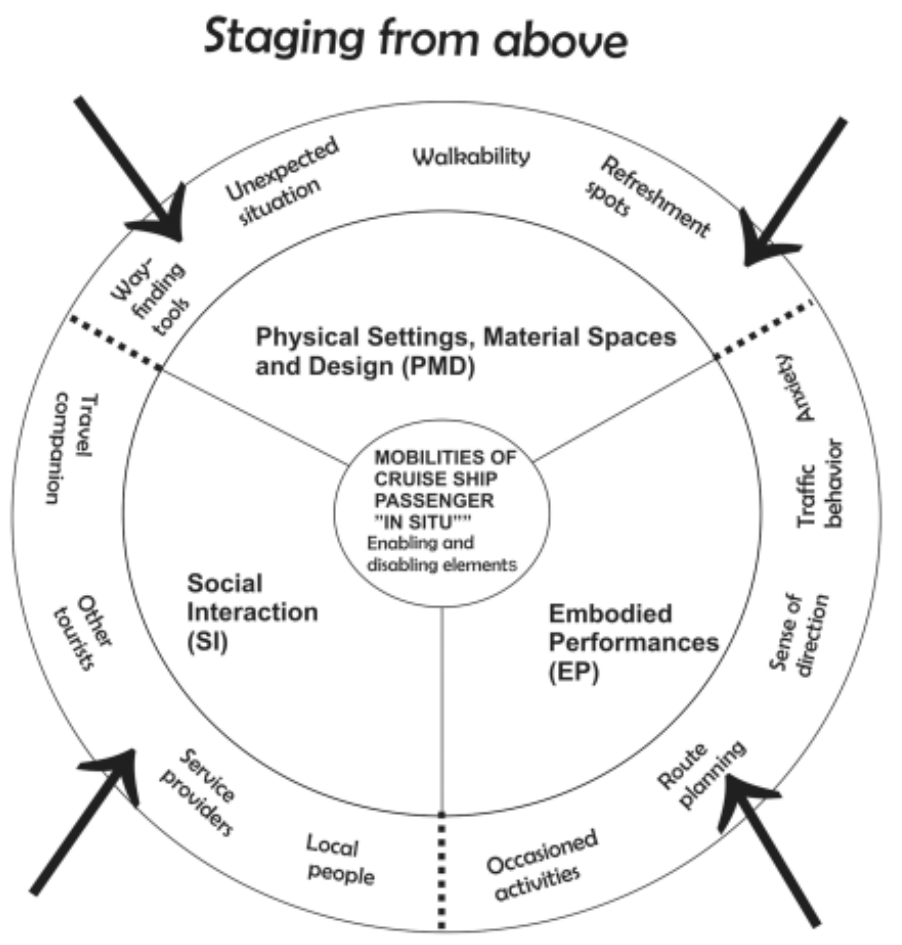

\section{Staging from below}

Figure 4: The staging mobility of cruise ship passengers in Helsinki, based on the staging mobilities framework. Source: Jensen (2013). (Authors' own production)

\section{PMD-related Disabling and Enabling Categories}

Data were combined into the following categories: wayfinding tools, unexpected obstacles, rest spots and walkability. The PMD dimension was the richest one compared to SI and EP, for its elements were immediately noticeable and easy to describe.

\section{Wayfinding tools}

The informants are leaving the Rock Church. Next destination is the Market Square. They are looking at the map outside the church for a long time. Along the 
way, they need to check the route many times, and they are taking a longer route.

(Notes taken while following a British group of friends of 50-55 years).

Wayfinding, in general, can be seen as a semiotic dimension, as individuals learn to read and use available signs. These tools help form mind maps more as they link different areas and landmarks in a logical way (Chang, 2015). For passengers arriving at the harbours, directional signs were among the most convenient mobility tools. They were especially important for passengers walking from Länsisatama and Hernesaari harbors. The location of the signs was interesting in the case of Hernesaari harbour, as they were located along a road that was not used by passengers, who were instead taking shortcuts through Kaivopuisto park; thus, those signs installed by city planning units (above staging) were missed by most visitors (below staging). Unfortunately, Kaivopuisto does not have directional signs, and therefore, tourists had to stop many times to read their maps. Also in the case of the Rock Church, disabling elements were mostly related to the lack of directional signs leading to the central tourist area. On the contrary, near the Market Square, lack of signs did not constitute a disabling element since many of the passengers used instead monuments as wayfinding tools. In Länsisatama harbour, directional-map stands proved to be enabling elements helping passengers to find their way more easily.

Wayfinding tools are vital for the use of public transportation, although as observed by Hall, Le-Klähn and Ram (2017), tourists often feel unsecure about the reliability of the information given. In Hernesaari harbour, finding the bus stop turned out to be difficult because of the presence of three bus stops next to each other. Inside the public transports, the main issue was to finding the right stop to get off. Some passengers were hoping for announcements or screen information about the attractions near the stops. After departing the vehicle, directional signs to the main tourist 
attractions would have been helpful, while passengers were instead disoriented for the long time required to find their location on the map. Using mobile devices as wayfinding tools were much appreciated while using public transportation. Often one person in the group was responsible for following the route on a map-based application in their mobile phones. On the other hand, walking passengers relied more on traditional maps.

\section{Unexpected situations}

The family is taking a sightseeing tram. All of a sudden the tram stops and then goes on a special route. No information was given in English, and the family is getting nervous. (Notes taken while following a family with mother, grandmother and two boys under 25 from Germany).

While moving, unexpected situations worked as disabling elements. Examples are in the construction sites located in both Länsisatama and Kanavaterminaali harbors. These places were the first encounter that passengers had with Helsinki, and the situations there required a lot of straying. Occasional breakdowns in public transportation are also within this category; they may cause anxiety, especially when the information is only provided in Finnish. Such situations miss the control of above staging, as they are unplanned and very rarely local administrations intervene promptly.

Rest spots

A couple arrives at the Länsisatama harbour and walks from there to the tourist area. In the middle of the walk, the man needs to use the toilet. They cannot find public toilets anywhere. They need to walk all the way to the Stockman department store, and the walk is disturbed by much anxiety. (Notes taken while following a couple over 65 from the US). 
The lack of free toilets along the long routes from the Hernesaari and Länsisatama harbors are surely disabling elements, as it is the lack of refreshment spots. Most passengers walking to the tourist area and especially the Market Square did not care to have coffee etc. since they had just left the ship; yet, some needed to rest, but the area did not offer free facilities.

\section{Walkability}

The group is taking pictures of the Uspenski Cathedral, but then a woman steps on a hole on the street that she had not noticed. She almost falls and feels strong pain in her hip where she had a surgery a few months ago. (Notes taken while following a British group of friends of 50-55 years).

Walkability is a wide concept with different definitions (Hall, Ram \& Shoval, 2018; Forsyth, 2015). According to Southworth (2005), it includes secure network of connections to different destinations, within a reasonable time and effort and at the same time providing pleasant and interesting context. Tourism-related walkability can be characterized by comfort, tourists appeal, activity potential, exploration (Samarasekara, Fukahori, \& Kubota, 2011; Ujang \& Muslim 2014; Ram \& Hall, 2018); however, in this study, the concept of walkability refers especially to fruition of landscapes and functional infrastructure for mobility.

There were 11 enabling comments detected about walkability. One of the best cases in Helsinki is represented by the walking route from Hernesaari harbor along the seaside. However, the mobility aesthetic, its enjoyment and possible distress do not only depend on objective material factors (above staging level) but also on subjectivity factors like tourists' previous experiences, cultural meaning given to observed elements, and behavioural patterns (below staging level). Some problems in the spatial and infrastructural conditions were seen as the cause of small accidents particularly near 
tourist attractions, where passengers concentrated more on tourism gazing than on looking at their pathways. Sometimes, tripping occurred in uneven paths, and incautiously even on bike lanes, with the risk of unexpected collision. This risk was higher especially around Market Square, where despite the relatively high traffic, inconspicuous marking of bike lanes and parking made pedestrians take wrong paths, which were understood as the most direct ones to get into the square.

\section{SI-related Disabling and Enabling Categories}

Within the social interaction, also in line with the three categories identified by Pierce (2005), we recognized the following elements: service providers, local people, travel companions, and other tourists.

\section{Service providers}

The family is traveling from Hernesaari harbour to the Rock Church. The bus driver does not speak English and is not able to sell them daily tickets. The family is confused, and the driver makes hand signals just to sit down. (Notes taken while following a Russian family composed of a 50-55 years old couple and four children under 25).

While using public transportation, the interaction between passengers and the driver was seen as an essential element of the negotiation in motion. The driver's response was based on language skills and helpfulness attitude. However, even though the situation suggested that the main driver was operating at the below staging, some conditions were given from above, since both the ships and public transport had to respect predetermined timetables, and this produced anxiety on both parties and pressure in the interaction. Some disabling elements were evident at the stops in the harbours. Although immobile, they are seen as temporary congregations (Jensen, 2013) since it is from those places that movements begin. 


\section{Local people}

The party is taking a tram from the harbour towards the Senate Square. They start to talk with a local man. He gives them advice on what to see and where to get off the tram. (Notes taken while following two American couples, over 60 years old).

Interactions that passengers have with other city users is more random and staged from below because of its unplanned nature since it is only produced if the parties want to. In some streets outside the tourist area, locals saw tourists looking into their maps and offered help. This is a significant interaction, and apart from cases when bad advice is given, it is enabling even when informational signs are present nearby because it provides help that is considered faster and more reliable by tourists.

Some negative confrontation with the locals occurred, when cruise passengers were walking too widely on the paths or blocking the routes, like in the case of the route from Hernesaari harbour that is a popular recreational route for locals. Additionally, as already reported, bikers and passengers had confrontations near Uspenski Cathedral, where the same path has to be used by both pedestrians and bikers. These situations are emphasized when locals and passengers show different traffic behaviour.

\section{Travel companions}

Children are looking bored after the visit to the Rock Church. While walking towards the historic city, they see a statue in front of the natural history museum. They want to visit the museum. One of the men says that there is no time. They continue to the historical city, and children are getting even more bored. (Notes taken while following a party with two couples, grandparents and four children under 12 years old from Germany).

During the observations, it was noticed that the category of travel companions worked as both enabling and disabling element. Earlier studies (e.g. Larsen, Axhausen, \& Urry, 
2006) have shown that trips are used also as a way to spend time within families and close friends since, in ordinary life, free time is lacking.

Cruise ships offer opportunities for family travels, with grown-up children and older parents. Often, adult children take responsibility and thus, constitute an enabling element of their parents' mobility. However, disabling elements may take place inside families, especially when groups include old people or small children. This was particularly obvious during the long walks from Hernesaari and Länsisatama harbours. Some older group members were walking at a slower pace, and this either annoyed the younger members or create anxiety especially in situations of time constraints.

Generational problems were observed when children were less interested in historical buildings while, instead, needed other leisure activities. Along with Jensen, (2013: 83) we also noted ongoing negotiation resulting in arguments and fights about where mobile withs, i.e. group of passengers moving together, should go.

\section{Other tourists}

Informants are walking from Hernesaari harbour and are following a British party. In Kaivopuisto Park, the Brits turn into the park. The Dutch first follow them, but then start to hesitate and look at the map. Then they decide to take another route. (Notes taken while following a young Dutch couple, 25-30 years old.

On a cruise, passengers often befriend other passengers they do not know beforehand (Teye \& Leclerc, 1998); but during short onshore times, arguments can be triggered by disabling factors. In our observation, this category was mentioned seven times as a disabling and eight times as an enabling element. While departing the ship in Helsinki, cruise-passengers often followed other passengers, even if these ones were not sure about the way. In some cases, different groups started exchanging opinions about routes, then going together at least for part of their journey to the city. This process 
could have both enabling and disabling elements.

\section{EP-related Disabling and Enabling Categories}

This section includes embodied performances factors that were mostly combined with others, already introduced. Identified elements were traffic behaviour, occasioned activities, sense of direction, travel planning and anxiety. Enabling elements, especially positively unexpected, were observed mostly on the seaside path between the major tourist area and Hernesaari harbour, while disabling elements were mostly concentrated in the city centre, and sometimes in Länsisatama harbour.

\section{Traffic behaviour}

The party includes a woman with a child in a stroller. They try to get into a tram from the first door. The driver does not let them in and shows the right door to use. The party buys a tram ticket for the woman, even though public transportation is free for a person traveling with a child in a stroller. (Notes taken while following a Spanish family, grandparents, man, and woman with three children under 15).

Often, and especially near Market Square, where there is heavy traffic, tourists showed bad behavior creating risky situations, such as jaywalking. This is an obvious case of a struggle between EP staged from below (traffic culture) and the material space (the crossroad that is planned above). Other traffic-related issues came up when using public transportation, for instance when tourists did not know what door to use to get into buses or trams.

\section{Occasioned activities}

The passenger's hobby is to take photos of flowers. Along the seaside route from Hernesaari harbor, there are several places with floral decorations, and this makes the woman excited so that she frequently stops to take pictures. (Notes taken while following an American group formed by a couple and friends, 55-60 years) 
Occasioned activities (Lyons \& Urry, 2005; Hannam et al., 2006) describe the situations where passengers follow own interests that become enabling elements of mobility. These situations occurred especially while walking from Länsisatama and Hernesaari harbours, where there were no classical tourist attractions, but passengers started observing everyday happenings that were somehow meaningful to them. In these situations, tourists produce new meanings and aesthetic experiences about what they find exciting while moving.

\section{Sense of direction}

The party arrives at Katajanokka harbor. They have problems finding the tram stop. Inside the tram, they ask a local person for some advice on how to get to the Market Square. Still, at the tram stop next to Senate Square, they go the wrong way. At the Market Square, they do not know the way back to the ship. (Notes taken while following a British group formed by a 50-55-year-old couple and the man's sister, 40-45-year-old and the mother, over 65 years old).

The process of finding a destination is different from one person to another (Golledge, 1999), and during the observation, it became evident that certain people had a good sense of direction and map reading skills, while others had frequent problems. In these situations showing features of mobile body semiotics (Jensen, 2013) the human body itself is a sort of a moving sign, and in the most positive case, a person with orientating skills operates as a wayfinding tool.

\section{Route planning}

The ship arrives at Länsisatama harbour, but the informant group does not know which port they are in. They start to follow the blue line that marks the walking route inside the construction site area. When the line ends, they do not know what to do, since they think that the line would have led them directly to the city centre. It takes them a long time to ponder where to go and with what mode of 
transportation. (Notes taken while following a group of two British couples, 55-60 years old).

In our observation, while certain passengers showed particularly careful planning, others were unprepared and did not even know the name of the port. Many passengers arriving straight into the tourist area were often just wandering around without any specific plan.

\section{Anxiety}

The man wants to take a bus, but other party members want to walk. He is constantly looking at his watch and making sure that others are walking briskly. (Notes taken while following a party with two couples, 55-60 years old, from Mexico).

Some examinees seemed to feel more anxiety about the time constraints than others did. These passengers were evidently more outcome-oriented tourists (Lew \& McKercher, 2006) since they aimed to reach the attractions quickly. Their anxiety could be seen as an embodied performance, as they expressed worries about how much time they were spending on walking, checked the time continuously and complained when others were stopping. Anxiety was then considered as a disabling element of movement that affected the mobility of travel companions.

\section{Discussion}

The research has looked at different kinds of enabling and disenabling aspects of mobility that independently moving passengers faced in situ during their visit inside the port of call of Helsinki. Each of the three dimensions presents diverse categories related to the mobility of cruise passengers: a) PMD: wayfinding, unexpected obstacles, lack of refreshment spots, and paths' walkability; b) SI: service providers, local people, travel 
companions and other tourists; and c) EP: traffic culture, sense of direction, planning, time-related anxiety and occasioned activities. Overall, the results show that SI and EP elements rarely occurred on their own. Instead, they were triggered by elements of PMD

Our study shows evident use of wayfinding tools while passengers move inside the destination independently. Wayfinding tools are usually conceived as elements of mobility staged from above; however, the results indicate that below elements enter the scene, because installed signs can be misplaced, or unnoticed and/or unfollowed. These findings are similar to those indicated by Andriotis and Agiomirgianakis (2010) showing that cruisers missed Heraklion's attractions because of the limited information and signage in there. Also Hamid (2014) observed in her qualitative study in Glasgow that appropriate positioning and design in street maps and signs are of upmost importance for tourism mobility.

Street signs are more meaningful in disembarking locations and in peripheries than in city centres, where tourists can use different wayfinding strategies, such as using notable landmarks that are easily traceable in paper maps. Time is always an issue for short time visitors like cruise passengers; hence, signs positioned at the harbours should indicate both distances and average walking times to tourist areas. In Jensen's (2014) words, embodied performances and body semiotics need to be addressed in planning, so directional signs should be readable in a universal way. Having good street signs can reduce the anxiety about the time. Also Chang (2015) in his study about wayfinding in Taipei, had identified some level of anxiety in his 86 study subjects walking through an unfamiliar city, and he also noted some individual differences, as it was evident in our observation of time-related anxiety, planning and sense of direction. A large amount of informants would have wanted to spend more time in the port of call. 
Our study revealed that mobile devices were used more as a wayfinding tool on public transportation. As noted again by Chang (2015), only a small group of users can see information on small screens like those of mobile phones. Using maps created various discussions and negotiations between the members of the travel parties. Hamid (2014) states that people still tend to refer to physical maps, travel books, or street maps when Wi-Fi connections are problematic and costly, especially during travels abroad. How abolishing the roaming tariffs in Europe will affect this behaviour is yet to be seen. The results of the study show that especially while moving from the harbours located further away, there are unique features in social interaction happening amongst the travel parties, i.e. customer to customer interaction (Huang \& Hsu, 2010). Yarnal and Kerstetter (2005) in their study on a Caribbean cruise argued that the ship is a liminal space and social relation among the passengers are a meaningful part of the cruise experience. In this current study, it was observed that while moving, travel party members whether just met on cruise or friends and family may have different interests, move with different speeds, or have different levels of orientation skills. All of these things were emphasized while the passengers were moving outside the actual tourism area. These issues are more evident when passengers have little time. For example families with children or/and elderly members had different walking speeds, and this affected the mobility of the whole group. Indeed, Nickerson and Jurowski (2001) in their survey based study about vacationing children had similar findings about children's difficulties in following adults in cities' sightseeing.

In different types of destination, like Kuala Lumpur (Malesia) described by Ujang and Muslim's (2014), the walking experience is enriched by various street activities that provide tourists' satisfaction either psychologically and functionally. In general, pedestrians find more pleasure to walk in built environments and natural areas, 
when places show social and cultural vitality (Michael Southworth, 2005). As for Helsinki, visitors find comfort in occasioned activities emerging from their interests and proactive roles. During our observations, passengers were trying to establish some meaningful contacts with the material environment through their embedded experiences, and to create original ways of enjoying the destination. Locations allow various dynamics of interactions and performances to occur, depending on the conditions supporting their mobility experience and contributing to their enjoyment, effective time management, or anxiety. However, in general, cruise passengers' engagement with the city is heavily reduced by the time limits and the very confusion between the various locations shortly visited during the overall trip.

Cleanliness in the walkways was not considered as relevant by tourists, although we noticed that some parts of the harbours were quite untidy. About safety perception, tourists in Helsinki did not feel any disabling elements like the risk of pickpocketing, which is common in many tourist areas worldwide, or the fear of terrorist attack that is often perceived in tourist destinations (Brunt, Mawby, \& Hambly, 2000) - although the Nice attack happened during the observation period.

The use of go-along observation framed within the staging mobilities model has supported the acquisition of different kinds of locational and qualitative data, with elements of the mobility experience interacting with others. This type of study can inform about some specific problems that are localized and having certain spatial distribution. Broader analysis on mobility and city development could support closer links between tourism planning and strategic urban planning; this goes beyond the potential of a limited technical study and enters the domain of political responsibility.

\section{Conclusion}

This study offers a contribution to the literature on cruise tourism and short-term 
mobility in ports of call. The findings suggest that the staging mobilities framework together with go-along methods allow examining enabling and disabling features of tourism mobility through more in-depth qualitative data. Although the method used was rather time-consuming and therefore, did not allow expanding the data collection further, it offers a dynamic and flexible mode of observing and classify visiting phenomena, and can be easily applied to other contexts, especially where short-term tourism is increasing. This kind of study could be also useful for urban planning in tourist cities: taking into primary consideration the spatial and functional needs of other city users and in particular, the mobility practices of the residents. Already some occasions of collision of paths, particularly along narrow pedestrian ways and bike lanes, have shown the importance of careful walkability planning. Recent international literature in both tourism and urban studies reflects on potential negative impacts that poorly planned tourism can cause in vulnerable urban areas, especially in historical centres. Like other studies have shown (e.g. Doxey, 1975; Minoia, 2017), growing tourism, and particularly fast tourism can produce deeper residential issues and conflicts, even starting by occasional disturbances on specific walkways.

Funding

This work was supported by the The Finnish Cultural Foundation Henrik Bitte Foundation, City of Helsinki and the Helsinki Tourism Foundation

Disclosure statement

No potential conflict of interest was reported by the authors.

Acknowledgements

1. Charlie Hornsby, the coder of the mobile application used in this study. 
References

Ahas, R., Aasa, A., Mark, Ü., Pae, T., \& Kull, A. (2007). Seasonal Tourism Spaces in Estonia: Case Study with Mobile Positioning Data. Tourism Management, 28(3), 898-910. doi: 10.1016/j.tourman.2006.05.010

Andriotis, K. \& Agiomirgianakis, G. (2010). Cruise Visitors' Experience in a Mediterranean Port of Call. International Journal of Tourism Research, 12(4), 390-404. doi: 10.1002/bjs.5677/

Aranburu, I., Plaza, B., \& Esteban, M. (2016). Sustainable Cultural Tourism in Urban Destinations: Does space matter? Sustainability (Switzerland), 8(8), 1-14. doi:10.3390/su8080699

Baker, D. M., \& Fulford, M. D. (2016). Cruise Passengers' Perceived Value and Willingness to Recommend. Tourism \& Management Studies, 12(1), 75-85. doi: $10.18089 /$ tms. 2016.12108

Bissell, D. (2010). Passenger mobilities: Affective atmospheres and the sociality of public transport. Environment and Planning D: Society and Space, 28(2), 270289. doi: $10.1068 / \mathrm{d} 3909$

Brida, J.G., Bukstein, D., Garrido, N. \& Tealde, E. (2010). Cruise Passengers' Expenditure in the Caribbean Port of Call of Cartagena de Indias: a Crosssection Data Analysis. Tourism Economies, 18(2), 607-634. doi: $0.5367 /$ te. 2012.0115

Brida, J. G., Pulina, M., Riaño, E., \& Zapata-Aguirre, S. (2012). Cruise Passengers' Experience Embarking in a Caribbean Home Port. The Case Study of Cartagena de Indias. Ocean and Coastal Management, 55, 135-145. doi: 10.1016/j.ocecoaman.2011.10.003

Brida, J. G., \& Zapata, S. (2010). Cruise Tourism: Economic, Socio-cultural and Environmental Impacts. International Journal of Leisure and Tourism Marketing, 1(3), 205. doi: 10.1504/IJLTM.2010.029585

Brunt, P., Mawby, R., \& Hambly, Z. (2000). Tourist Victimisation and the Fear of Crime on Holiday. Tourism Management, 21(4), 417-424. doi: 10.1016/S02615177(99)00084-9

Carić, H. (2016). Challenges and Prospects of Valuation - Cruise Ship Pollution Case. Journal of Cleaner Production, 111, 487-498. doi: 10.1016/j.jclepro.2015.01.033 
Çetin Demirel, N., \& Yücenur, G. N. (2011). The Cruise Port Place Selection Problem with Extended VIKOR and ANP Methodologies Under Fuzzy Environment. Proceedings of the World Congress on Engineering 2011, WCE 2011, 2. pp. 1128-1133).

Chang, H. H. (2015). Which one helps tourists most? Perspectives of international tourists using different navigation aids. Tourism Geographies, 17(3), 350-369. doi: 10.1080/14616688.2015.1016099

Cresswell, T. (2006). On the Move: Mobility in the Modern Western World. New York: Routledge.

Cruise Lines International Association (CLIA). (2015). Annual Report. Retrieved from https://www.cruising.org/about-the-industry/research/2015-annual-report

Cruise Market Watch. (2016). Growth. Retrieved from http://www.cruisemarketwatch.com/growth/

De Cantis, S., Ferrante, M., Kahani, A., \& Shoval, N. (2016). Cruise Passengers' Behavior at the Destination: Investigation Using GPS Technology. Tourism Management, 52, 133-150. doi: 10.1016/j.tourman.2015.06.018

Diedrich, A. (2010). Cruise ship tourism in Belize. The implications of developing cruise ship tourism in an ecotourism destination. Ocean \& Coastal Management,(5-6), 234-244.

Doxey, G. (1975). The Causation Theory of Visitor-resident Irritants: Methodology and Research Inferences. Proceedings of the Travel Research Association, 6th Annual Conference, 195-198.

Edwards, D., \& Griffin, T. (2013). Understanding Tourists' Spatial Behaviour: GPS Tracking as an Aid to Sustainable Destination Management. Journal of Sustainable Tourism, 21(4), 580-595. doi: 10.1080/09669582.2013.776063

Ferrante, M., De Cantis, S., \& Shoval, N. (2016). A General Framework for Collecting and Analysing the Tracking Data of Cruise Passengers at the Destination. Current Issues in Tourism. 21(12), 1-26 doi: 10.1080/13683500.2016.1194813

Finlay, J., \& Bowman, J. (2017). Geographies on the Move: A Practical and Theoretical Approach to the Mobile Interview. Professional Geographer, 69(2), 263-274. doi: $10.1080 / 00330124.2016 .1229623$

Forsyth, A. (2015). What is a walkable place? The walkability debate in urban design. Urban Design International, 20(4), 274-292. doi: 10.1057/udi.2015.22 
Fullagar, S; Wilson, E; Markwell, K. (2012). Starting Slow: Thinking Through Slow Mobilities and Experiences. In E. Fullagar, S; Markwell, K; Wilson (Ed.), Slow tourism : experiences and mobilities (pp. 1-11). Bristol, Buffalo, Toronto: Chanel View Publications.

Golledge, G. G. (1999). Wayfinding Behavior: Cognitive Mapping and Other Spatial Processes. Baltimore: JHU Press.

G.P. Wild (International Limited and Business Research and Economic, 2015). (2015). Overview Cruise Passenger and Crew Surveys Helsinki. Retrieved from the city of Helsinki.

Hall, C.M., Le-Klähn, D-T., \& Ram, Y. (2017). Tourism, Public Transport and Sustainable Mobility. Bristol: Channel View Publication.

Hall, C.M., Ram, Y. \& Shoval, N. (2018). Introduction. Walking - more than pedestrian. In C. M. Hall, Y. Ram, \& N. Shoval (Ed.), The Routledge International Handbook of Walking. Bristol: Channel View Publication.

Hamid, S. A. (2014). Walking in the City of Signs: Tracking Pedestrians in Glasgow. Current Urban Studies, 2, 263-278. doi: 10.4236/cus.2014.23025

Hannam, K., Sheller, M., \& Urry, J. (2006). Editorial: Mobilities, Immobilities and Moorings. Mobilities, 1(1), 1-22. doi: 10.1080/17450100500489189

Henthorne, T.L. (2000). An analysis of expenditures by cruise ship passengersin Jamaica. Journal of Travel Research, 38(3), 246-250.

Huang, J., \& Hsu, C. H. C. (2010). The impact of customer-to-customer interaction on cruise experience and vacation satisfaction. Journal of Travel Research, 49(1), 79-92. doi: 10.1177/0047287509336466

Jaakson, R. (2004). Beyond the Tourist Bubble? Cruiseship Passengers in Port. Annals of Tourism Research, 31(1), 44-60. doi: 10.1016/j.annals.2003.08.003

Jensen, O. B. (2013). Staging Mobilities. New York: Routledge.

Jensen, O. B. (2014a). Designing Mobilities. Aalborg: Aalborg Universitetsforlag.

Jensen, O. B. (2014b). Mobilities Design - Towards a "New Materials Turn.” Mobilities and design work shop, Lancaster, UK.

Jordan, E. J., \& Vogt, C. A. (2017). Residents' Perceptions of Stress Related to Cruise Tourism Development. Tourism Planning and Development, 14(4), 527-547. doi: $10.1080 / 21568316.2017 .1287123$

Judd, D. R. (1999). Constructing the Tourist Bubble. In S. Judd, D; Feinstein (Ed.), Tourist City (pp. 35-53). New Haven, CT: Yale University Press. 
Kang, S. (2016). Associations between space-time constrains and spatial patterns of travels. Annals of Tourism Research 61, 127-141

Kusenbach, M. (2003). Street Phenomenology. Ethnography, 4(3), 455-485. doi: $10.1177 / 146613810343007$

Kusenbach, M. (2012). Go-Alongs. In A. Delamont (Ed.), Handbook of Qualitative Research in Education (pp. 252-264). Cheldenham, UK \& Northampton, MA, USA: Edward Elgar Publishing

Lanng, D.B. \& Jensen, O. (2016). Linking Wayfinding and Wayfaring. In B. L. Hunter R.H. Andeson \& L.A.Belza (Ed.), Community Wayfinding: Pathways to Understanding (pp. 247-260). Switzerland: Springer Nature.

Larsen, J. (2001). Tourism mobilities and the travel glance: Experiences of being on the move. Scandinavian Journal of Hospitality and Tourism, 1(2), 80-98. doi: $10.1080 / 150222501317244010$

Larsen, J., Axhausen, K. W., \& Urry, J. (2006). Geographies of Social Networks: Meetings, Travel and Communications. Mobilities, 1(2), 261-283. doi: $10.1080 / 17450100600726654$

Larsen, S., \& Wolff, K. (2016). Exploring assumptions about cruise tourists' visits to ports. Tourism Management Perspectives, 17, 44-49. doi: 10.1016/j.tmp.2015.12.001

Lew, A., \& McKercher, B. (2006). Modeling Tourist Movements: A Local Destination Analysis. Annals of Tourism Research, 33(2), 403-423. doi: 10.1016/j.annals.2005.12.002

Lynch, K. (1960). The Image of the City. Cambridge, MA: The M.I.T Press.

Lyons, G. \& Urry, J. (2005). Travel Time Use in the Information Age. Transportation Research 39(2). 257-276.

Manning, T. (2006). Managing Cruise Ship Impacts: Guidelines for Current and Potential Destination Communities A Backgrounder for Prospective Destination Communities. Retrieved from http://www.tourisk.org/content/projects/Managing Cruise Ship Impacts.pdf

Marti, B. E. (1990). Geography and the Cruise Ship Port Selection Process. Maritime Policy and Management, 17(3), 157-164. doi: 10.1080/03088839000000023

McCalla, R. (1998). An investigation into site and situation: Cruise ship ports. Tijdschrift voor Economische en Sociale Geografie,89(1), 44-55. 
McKercher, B., Shoval, N., Ng, E., \& Birenboim, A. (2012). First and Repeat Visitor Behaviour: GPS Tracking and GIS Analysis in Hong Kong. Tourism Geographies, 14(1), 147-161. doi:10.1080/14616688.2011.598542

Minoia, P. (2017). Venice reshaped? Tourist gentrification and sense of place. In N. Bellini \& C. Pasquinelli (Eds.), Tourism in the City. Towards an Integrative Agenda on Urban Tourism (pp. 261-274). Cham: Springer.

Nickerson, N. P., \& Jurowski, C. (2001). The Influence of Children on Vacation Travel Patterns. Journal of Vacation Marketing, 7(1), 19-30. doi: $10.1177 / 135676670100700102$

Papathanassis, A., \& Beckmann, I. (2011). Assessing the "Poverty of Cruise Theory" Hypothesis. Annals of Tourism Research, 38(1), 153-174. doi: 10.1016/j.annals.2010.07.015

Pearce, P.L. (2005). Tourist Behaviour: Themes and Conceptual Schemes. Clevedon: Chanel View Publications.

Penco, L., \& Di Vaio, A. (2014). Monetary and Non-monetary Value Creation in Cruise Port Destinations: an Empirical Assessment. Maritime Policy and Management, 41(5), 501-513. doi: 10.1080/03088839.2014.930934

Port of Helsinki (2017, January, 20). Annual Report 2016. Retrieved from http://www.portofhelsinki.fi/sites/ default/files/attachments/Vuosikertomus 2016 englanti low res.pdf

Ram, Y. \& Hall, C. M. (2018). Walkable Places for Visitors. Assessing and Designing for Walkability. In C. M. Hall, Y. Ram, \& N. Shoval (Ed.), The Routledge International Handbook of Walking. Bristol: Channel View Publication.

Rodrigue, J. P., \& Notteboom, T. (2013). The Geography of Cruises: Itineraries, not Destinations. Applied Geography, 38(1), 31-42. doi: 10.1016/j.apgeog.2012.11.011

Samarasekara, G. N., Fukahori, K., \& Kubota, Y. (2011). Environmental Correlates That Provide Walkability Cues for Tourists: An Analysis Based on Walking Decision Narrations. Environment and Behavior, 43(4), 501-524. doi: $10.1177 / 0013916510379350$

Satta, G., Parola, F., Penco, L., \& Persico, L. (2015). Word of Mouth and Satisfaction in Cruise Port Destinations. Tourism Geographies, 17(1), 54-75. doi:10.1080/14616688.2014.938689 
Sheller, M., \& Urry, J. (2006). The New Mobilities Paradigm. Environment and Planning A, 38(2), 207-226. doi: 10.1068/a37268

Shoval, N., \& Ahas, R. (2016). The Use of Tracking Technologies in Tourism Research: The First Decade. Tourism Geographies, 18(5), 587-606. doi: $10.1080 / 14616688.2016 .1214977$

Shoval, N., \& Isaacson, M. (2007). Tracking tourists in the digital age. Annals of Tourism Research, 34(1), 141-159. doi: 10.1016/j.annals.2006.07.007

Silvestre, A.L., Santos, C.M. \& Ramalho, C. (2008). Satisfaction and Behavioural Intentions of Cruise Passengers Visiting the Azores. Tourism Economies, 14(1), 169-184. doi:10.5367/000000008783554802

Southworth, M. (2005). Designing the Walkable City. Journal of Urban Planning and Development, 131(4), 246-257. doi: 10.1061/(ASCE)0733-9488

Sönmez, S. F., \& Graefe, A. R. (1998). Influence of Terrorism Risk on Foreign Tourism Decisions. Annals of Tourism Research, 25(1), 112-144. doi: 10.1016/S01607383(97)00072-8

Teye, V. B., \& Leclerc, D. (1998). Product and Service Delivery Satisfaction among North American Cruise Passengers. Tourism Management, 19(2), 153-160. doi:10.1016/S0261-5177(97)00107-6

Tranberg Jensen, M., Gyimothy, S., \& Jensen, O. B. (2015). Staging Interrail Mobilities. Tourist Studies, 16(2), 111-132. doi: 10.1177/1468797615594740

Ujang \& Muslim (2014). Walkability and Attachment to Tourism Places in the City of Kuala Lumpur, Malaysia. ATINER's Conference Paper Series, March 2014, 117.

Urry, J. (2000). Mobile Sociology 1. The British Journal of Sociology, 51(1), 185-203. doi: $10.1111 / \mathrm{j} .1468-4446.2000 .00185 . \mathrm{x}$

Urry, J. (2010). Mobile Sociology. British Journal of Sociology, 61( s1), 347-366. doi:10.1111/j.1468-4446.2009.01249.x

Veijola, S., \& Falin, P. (2016). Mobile neighbouring. Mobilities, 11(3), 382-399. doi:10.1080/17450101.2014.936715

Visit Helsinki. (2016). Helsinki was Visited by 409000 International Cruise Ship Passengers in the Year 2016 (Helsingissä kävi kesällä 409000 kansainvälistä risteilymatkustajaa). Retrieved from http://www.visithelsinki.fi/fi/ammattilainen/media/uutishuone/helsingissa-kavikesalla-409-000-kansainvalista-risteilymatkustajaa 
Wood, R. E. (2000). Caribbean Cruise Tourism: Globalization at Sea. Annals of Tourism Research, 27(2), 345-370. doi:10.1016/S0160-7383(99)00073-0

Xie, H. J., Kerstetter, D. L., \& Mattila, A. S. S. (2012). The Attributes of a Cruise Ship that Influence the Decision Making of Cruisers and Potential Cruisers. International Journal of Hospitality Management, 31(1), 152-159. doi:10.1016/j.ijhm.2011.03.007

Yarnal, C. M., \& Kerstetter, D. (2005). Casting off: An exploration of cruise ship space group tour behavior, and social interaction. Journal of Travel Research, 43(4), 368-379. doi:10.1177/0047287505274650

Zheng, W., Huang, X., \& Li, Y. (2017). Understanding the tourist mobility using GPS: Where is the next place? Tourism Management, 59, 267-280. doi:10.1016/j.tourman.2016.08.009 